ECONOMIC GROWTH CENTER

YALE UNIVERSITY

P.O. Box 208629

New Haven, CT 06520-8269

http://www.econ.yale.edu/ egcenter/

CENTER DISCUSSION PAPER NO. 897

\title{
ADJUSTING HOUSEHOLD STRUCTURE: SCHOOL ENROLLMENT IMPACTS OF CHILD FOSTERING IN BURKINA FASO
}

\author{
Richard Akresh \\ University of Illinois at Urbana-Champaign
}

November 2004

Notes: Center Discussion Papers are preliminary materials circulated to stimulate discussions and critical comments.

I thank Michael Boozer, Kevin Hallock, Ilana Redstone, Paul Schultz, Tavneet Suri, Christopher Udry, and seminar participants at the BREAD and NEUDC conferences and at Yale University for helpful comments and suggestions. I acknowledge the collaboration between Yale University and l'Unité d'Enseignement et de Recherche en Démographie of the University of Ouagadougou that aided the data collection. I thank the following organizations for financial support: National Science Foundation (Grant No. 0082840), Social Science Research Council, J. William Fulbright Fellowship, National Security Education Program, Institute for the Study of World Politics, and Yale Center for International and Area Studies. Finally, I thank the members of the field research team, in particular the field supervisor, Ouedraogo Touende Bertrand, and the data entry supervisor, Hubert Barka Traore. Contact information: University of Illinois at Urbana-Champaign, Department of Economics, 504 E. Armory Avenue, Champaign, IL 61820. Email: akresh@uiuc.edu.

This paper can be downloaded without charge from the Social Science Research Network electronic library at: http://ssrn.com/abstract=614482

An index to papers in the Economic Growth Center Discussion Paper Series is located at: http://www.econ.yale.edu/ egcenter/research.htm 


\title{
Adjusting Household Structure: School Enrollment Impacts of Child Fostering in Burkina Faso
}

\author{
Richard Akresh
}

\begin{abstract}
Researchers claim that children growing up away from their biological parents may be at a disadvantage and have lower human capital investment. This paper measures the impact of child fostering on school enrollment and uses household and child fixed effects regressions to address the endogeneity of fostering. Data collection by the author involved tracking and interviewing the sending and receiving household participating in each fostering exchange, allowing a comparison of foster children with their non-fostered biological siblings. Foster children are equally likely as their host siblings to be enrolled after fostering and are 3.6 percent more likely to be enrolled than their biological siblings. Relative to children from non-fostering households, host siblings, biological siblings, and foster children all experience increased enrollment after the fostering exchange, indicating fostering may help insulate poor households from adverse shocks. This Pareto improvement in schooling translates into a long-run improvement in educational and occupational attainment.
\end{abstract}

Keywords: Human capital investment, Child fostering, Household structure

JEL Codes: J12, I20, O15, D10 


\section{Introduction}

Children comprise the majority of the population in many African countries and represent the region's future. If they lack the skills and knowledge needed to lead productive lives, Africa's economic development might be limited and its ability to reduce poverty jeopardized (World Bank, 2003). Most international development organizations and many academic researchers believe that the widespread institution of child fostering, in which parents send their own biological children to live with another family, has negative consequences for that child's human capital investment and welfare outcomes (Bledsoe and Brandon, 1989; Haddad and Hoddinott, 1994; Kielland, 1999; UNICEF, 1999; Case, Lin, McLanahan, 2000; Bishai et al., 2003; Fafchamps and Wahba, 2004).

A child living away from his biological parents might be more likely to work, might experience psychological problems, or might suffer due to the disruption of living away from his siblings. It is also possible these children could benefit both in the short and long-run from the fostering experience by having access to schools, receiving better nutrition, or exposure to an expanded social network. The impact of fostering, on the foster child, his biological siblings who remained behind, and his host siblings in the receiving household, is an empirical question.

This paper uses data collected by the author during eighteen months of fieldwork in Burkina Faso to measure the impact of child fostering on school enrollment. ${ }^{1}$ Previous researchers have used cross-sectional data to evaluate the effect of children not residing with their biological parents, but cross-sectional data can only compare the current enrollment status for foster children with that of their non-fostered host family siblings (Case, Lin, McLanahan, 2000; Zimmerman, 2003). Their results will be biased if there is some unobservable factor omitted from the analysis that is correlated with both fostering and school enrollment.

\footnotetext{
${ }^{1}$ According to these data, approximately 27 percent of households either sent or received a foster child between 1998 and 2000, and these children spent, on average, 2.75 years living away from their parents.
} 
The data include three years of retrospective information which I use to estimate a fixed effects regression that measures the effect of fostering on school enrollment and deals with the potential biases arising from using cross-sectional data. While cross-sectional results suggest that only 17.6 percent of foster children are enrolled compared to 31.1 percent of host family siblings (Table 1), controlling for the child's enrollment status prior to the fostering episode indicates that, when compared to the host family siblings they live with, foster children are no worse off after moving away from their biological parents. The fixed effects approach shows that not controlling for omitted variables in measuring the welfare impacts of child fostering can yield seriously misleading results.

During the data collection, I located the sending and receiving household participating in each fostering exchange. This research methodology makes these data particularly appropriate for understanding the impact of fostering, not only on the foster child and the host siblings, but also on the biological siblings who stayed behind. The results show that after being fostered, foster children are, on average, 3.6 percent more likely to be enrolled when compared to their non-fostered biological siblings, and the impact is larger for young children. However, these results mask substantial heterogeneity depending on the reason for the fostering and where the sending and receiving households live. ${ }^{2}$ Children who, according to their parents, were fostered for schooling reasons are significantly more likely to experience a positive welfare outcome in terms of school enrollment compared to children fostered for child labor reasons.

The fixed effects regressions in this analysis control for household level unobservables and provide evidence that after a household selects which child to send, there is a strong positive impact of the fostering on that child's enrollment, relative to both the child's host and biological siblings. ${ }^{3}$

\footnotetext{
${ }^{2}$ Evidence of this welfare outcome heterogeneity is also seen in rural Mali where children who were requested by the receiving family had better nutritional outcomes than children sent due to crisis fostering (Castle, 1995).

${ }^{3}$ A related empirical literature that attempts to understand why households foster children finds that the demand for child labor, risk-coping in response to exogenous income shocks, human capital investment in the child, parent death, and high quality social networks are possible motivations for why a household decides to send out a child (Isiugo-Abanihe, 1985; Page, 1989; Ainsworth, 1996; Zimmerman, 2003; Akresh, 2004; Cichello, 2004). In addition,
} 
However, the biological parents are probably selecting the child with the best chance to succeed in the host household. The decision of which child the biological parents foster may be based on factors that are unobservable to the researcher but which clearly influence how well the child does in the host household. To control for these factors, I estimate a child fixed effects regression that measures the impact of fostering on that child's educational enrollment, conditional on the child's unobserved attributes. The results suggest foster children after leaving their parents are neither worse nor better off relative to their host and biological siblings. Conditional on the child's type (via the child fixed effects regression), there is no school enrollment impact following the fostering, as opposed to a positive enrollment impact when the biological parents have knowledge about these unobservable factors and make an optimization decision about which child to send out.

The data allow me to compare these three groups of children (host siblings, biological siblings, and foster children) with children who live in households that never fostered a child. In both household and child fixed effects specifications, foster children are better off after the fostering compared to children from non-fostering households, and the impact is larger for young children. In addition, in the child fixed effects regressions, the host and biological siblings are better off after the fostering compared to the non-fostering household's children. The results provide evidence that the institution of child fostering and the ability of a household to send out a child when it needs to can lead to a Pareto improvement in school enrollment for all children involved: the host siblings in the receiving family, the biological siblings remaining behind in the sending family, and the foster child. This Pareto improvement is the major finding of this paper, and it appears to stem from the ability of African households to ease the constraint of a purely biological notion of a household. ${ }^{4}$

theoretical work by Serra (2003) argues that demand for child labor by the host family and aspirations for human capital investment by the biological family could simultaneously explain a given fostering exchange.

${ }^{4}$ There is a growing literature trying to measure the impact of orphanage on children's school enrollment (Ainsworth, Beegle and Koda, 2002; Case, Paxson, Ableidinger, 2004; Evans and Miguel, 2004; Gertler, Levine, and Ames, 2004; Yamano and Jayne, 2004), and while parent death is one of several reasons why children are fostered, the data used in this paper contain only 23 children who were fostered for that reason. Therefore, the 
In addition to measuring short-run welfare improvements in schooling, I can also evaluate the long-run impacts of a fostering experience. I find a strong positive correlation between current wealth (measured as current assets or income) and the survey respondent having been fostered as a child, even after controlling for observable characteristics of the respondent and the respondent's biological parents. Stronger evidence of a positive long-run return to fostering is provided by household fixed effects regressions comparing brothers and sisters from the same family and controlling for unobservable factors that might be correlated with fostering and current wealth. Those siblings, from a given family, that were fostered as children are more likely to be educated and have occupations with higher earnings such as a businessman, government employee, or teacher and are less likely to be a farmer and live in a rural village. These results are important for understanding why a household adjusts its structure and the long and short-run implications of that decision.

The remainder of the paper is organized as follows. Section 2 describes the empirical setting for the data collection. In Section 3, I describe the empirical identification strategy. Section 4 presents the empirical results and Section 5 concludes.

\section{Data and Empirical Setting}

\subsection{Empirical Setting}

The data were collected in Bazega province in central Burkina Faso, located approximately fifty miles from the capital, Ouagadougou. ${ }^{5}$ Households in this region consist predominantly of subsistence farmers growing millet, sorghum, and groundnuts and have an average annual income of $\$ 183$ (based on an average foreign exchange rate from 1998 to 2000 of $\$ 1=641$ FCFA). On average,

conclusions from this paper may not generalize to the case of orphaned children.

${ }^{5}$ More detailed information about the fieldwork, including the survey instruments, field enumerator training manuals, and project reports can be found on the website: https://netfiles.uiuc.edu/akresh/www 
these households have 10.6 members consisting of a household head, 1.5 wives, 3.6 children under age 18, 3.2 children over age 18, and 1.3 members that might include the household head's mother, brothers, sisters, grandchildren, distant relatives, and individuals with no direct relationship.

The fieldwork component of the project improved on previous studies in several ways. First, I adopted a methodology that involved locating and interviewing the sending and receiving households of each fostering exchange. For example, if a household interviewed in the initial sample had sent a child to another family, then the receiving household was found and interviewed in the tracking phase of the survey. Similarly, if a household interviewed in the initial sample had received a child, then the biological parents of the child (sending household) were located and interviewed. This is the first time that both the sending and receiving household from a given fostering exchange had been tracked and interviewed, and it enables a better understanding of the impact of the fostering not only on the host siblings and the foster child (which is possible with some existing datasets), but also on the foster child's biological siblings who stayed behind.

Second, I asked retrospective questions covering the years 1998 to 2000 concerning the child's school enrollment history. This information allows me to compare enrollment before and after the fostering exchange and to measure more accurately the impact of fostering. Most datasets collected in Africa do not have school enrollment information covering a three year time period and researchers must instead rely on cross-sectional comparisons using current enrollment. Third, I collected information from the respondents about the childhood fostering status and occupational and educational attainment of their siblings in order to measure the long-term impact of fostering while controlling for household level unobservables.

The survey consisted of two distinct phases. The initial phase entailed interviews with 606 household heads and their 812 wives in fifteen randomly selected villages in Bazega province. In these villages, the unit of analysis for the sampling frame was the compound, with some compounds 
containing multiple households. ${ }^{6}$ Within each compound, an enumerator individually interviewed the head of every household and then separately interviewed all of his wives, if applicable. ${ }^{7}$

The tracking phase of the survey consisted of finding the 316 paired households that had exchanged a foster child and interviewing the head of each household along with all of his wives using the same survey instrument as the initial phase. I restricted the tracking to those households that had exchanged a foster child between 1998 and 2000 and where the child's age at the time of fostering was between five and fifteen inclusive.

Children under age five were excluded from the tracking for three reasons. First, these children cannot be enrolled in school. Second, researchers studying child fostering in Africa have argued that young children are fostered for different reasons than older children (Vandermeersch, 2002). In particular, young children are not routinely performing domestic chores and are essentially just consumers. Around age five, children are expected to become economic contributors to the family, undertaking tasks in the household, fields, and marketplace. At this time, a household would become concerned with human capital investment and possibly with offsetting demographic imbalances in the number of its children of a given age and gender. Third, results from this survey confirm that fostering of young children is much less common than older children, showing a significant jump in fostering rates at age six. Approximately one percent of children under age five were fostered between 1998 and 2000, compared to ten percent of children aged five to fifteen.

Children aged sixteen and older were also excluded from the tracking because, at that age,

\footnotetext{
${ }^{6}$ To increase the number of households in the sample that had fostered children, I adopted a two part sampling frame that included a random sample and a choice-based sample both drawn from a village level census that included information about the fostering status of every household (for more details, see Akresh, 2004b). The choice-based sample consisted of compounds that had fostered a child between 1998 and 2000. All results in this paper use the entire sample, but results are qualitatively similar when I restrict the observations to just the random sample. Using the population fostering weights from the village level census to adjust the choice-based sample does not significantly alter the results. A total of 383 compounds containing 606 households were selected with approximately sixty percent of the compounds in the random sample.

${ }^{7}$ The particular household definition (described in Akresh, 2004b) that assigned every individual living in the compound to a specific household was implemented to ensure that individuals in the compound who might have been involved in making a fostering decision would be interviewed.
} 
most villagers in rural Burkina Faso would consider them adults. They are physically mature, have passed initiation rites, and females are of an acceptable age for marriage. In addition, for older children, it becomes difficult to disentangle what is child fostering and what is an example of a household splitting off members to form distinct and separate households.

The success of the tracking phase makes these data particularly unique and appropriate for measuring the impact of fostering on school enrollment. Approximately sixty percent of the paired households were located within a twenty-five mile radius of the child's home, twenty-five percent were located in the capital fifty miles away, six percent were scattered across the other provinces of Burkina Faso about one hundred and fifty miles away, and nine percent were in Côte d'Ivoire approximately eight hundred miles away. There were 316 paired households to be found during the tracking phase, and the field research team located 94.9 percent of them, 300 households in total. ${ }^{8}$

\subsection{Data}

In addition to the 316 foster children, in the sending households, there were 994 biological siblings who have never been fostered, and in the receiving households, there were 640 host siblings who had never been fostered. Analyzing the school enrollment rates for these different groups of children in Table 1 shows that foster children and the biological siblings they left behind have similar average enrollment rates (17.6 percent for foster children and 19.5 percent for biological siblings). However, children in the host households have a much higher average enrollment rate of 31.1 percent. Average age is similar across the three groups of children ranging from 9.7 to 10.4 years old, but foster

\footnotetext{
${ }^{8}$ The sixteen tracked households that were not interviewed included four households (three in the capital and one in Côte d'Ivoire) that were found but refused to be surveyed, four households in the capital in which the child left the village in search of work and had not yet contacted his biological parents to indicate the family with whom he was now living, two households where the parents left children in the village in Burkina Faso and went to work in Côte d'Ivoire but the receiving household did not have information to locate them, and three households (two in Côte d'Ivoire and one in Togo) that had contacted the parents to inform them they were moving towns and would send more contact information once they were settled. Finally, the remaining three cases included issues of disputed paternity, alleged adultery, and confirmed sorcery.
} 
children are more likely to be girls.

Table 2 analyzes how children's school enrollment changes over time before and after the fostering episode. Many development organizations are concerned that after a child is sent away from his biological parents he will stop attending school, but the data do not confirm this. Only two percent of foster children were no longer enrolled after being sent to the host household despite being enrolled prior to the fostering. This compares with 3.3 percent of host siblings and 2.3 percent of biological siblings who discontinued enrollment after the fostering exchange. Following the fostering, approximately the same percentage of children in each group were newly enrolled students, with rates ranging from 4.5 to 4.9 percent. The largest difference between the three groups is the percentage of children who were never enrolled. There are 82.7 percent of foster children and 77.9 percent of biological siblings in this category, but only 60.5 percent of host siblings were never enrolled. I can reject the null hypothesis that the percentage of children in each transition group (never enrolled, discontinued enrollment, newly enrolled, and enrolled both years) is the same across host siblings, biological siblings, and foster children with a likelihood ratio $\chi^{2}(6)$ test statistic of 51.00 and a corresponding $\mathrm{p}$-value of 0.00 . However, the likelihood ratio $\chi^{2}(3)$ test statistic testing for equality between foster children and biological siblings cannot be rejected with a p-value of 0.34 .

\section{Empirical Strategy}

\subsection{Empirical Identification in Previous Research}

Several recent empirical papers attempt to measure the school enrollment impact of children living away from their biological parents. Most of these papers use cross-sectional data and compare school enrollment for children living with their biological parents with that of foster children living without their parents. However, current school enrollment is partly a function of that child's school 
enrollment history. Without controlling for that history prior to the fostering, the researcher will incorrectly measure the fostering impact. Foster children are more likely to come from households that experienced negative income shocks (Akresh, 2004), and due to these shocks, it is likely the child's parents could not afford the school fees and the child was not enrolled prior to the fostering (Thomas et al., 2004). As a consequence, if the host family maintains the foster child's pre-fostering enrollment status, in a cross-sectional comparison it will appear that the foster child is worse off compared to non-fostered children. Using cross-sectional data to measure this impact would yield misleading results if there are factors (such as school enrollment history, wealth, or network quality) omitted from the regressions that are correlated with both fostering and school enrollment.

Lloyd and Blanc (1996) use Demographic and Health Surveys (DHS) from seven countries in sub-Saharan Africa and show that children's school outcomes (measured by current school enrollment and grade four completion) are more influenced by characteristics of the child's extended family network and the household in which the child resides than by characteristics of his biological parents. Zimmerman (2003), using 1993 household survey data from South Africa, finds that the risk for foster children of not attending school is lower than it would have been if the child had stayed with his biological parents. Both studies rely on cross-sectional data which are subject to the aforementioned problems. Overall, some researchers have found similar results to Zimmerman (Eloundou-Enyegue and Shapiro, 2004), while others have found that foster children are less likely to be enrolled and more likely to be working (Kielland, 1999). Cichello (2004) extends Zimmerman's analysis by incorporating information from a 1998 survey collected on a sub-sample of the households used by Zimmerman. This allows him to construct a school progress measure defined as the number of additional years of schooling attained between 1993 and 1998. He finds there are no positive gains for foster children in terms of school progress, despite higher initial school enrollment in 1993. Despite using the additional 1998 information to develop an improved measure of human 
capital investment, Cichello is not able to address the endogeneity of fostering.

Related research attempts to measure the school enrollment impact when a child's parent dies. As parent death is one of several reasons why children are fostered, it is informative to understand the empirical estimation strategies employed in that literature. Several papers use cross-sectional data to estimate this impact of orphanage on enrollment (Ainsworth and Filmer, 2002; Case, Paxson, and Ableidinger, 2004; Gertler, Levine, and Ames, 2004), but the results are subject to potential biases due to omitted variables being correlated with both orphanage and enrollment. There are two papers that address the endogeneity problem by using the time dimension in a panel dataset to estimate a child fixed effects regression (Evans and Miguel, 2004; Yamano and Jayne, 2004). With this estimation strategy they are able to control for time-invariant factors, such as wealth and network quality, that might be correlated with both orphanage and school enrollment.

These papers studying orphans have the advantage that parent death might be unexpected and measuring the schooling impact due to this potentially exogenous event seems straightforward. However, these papers focus on only one of the reasons why a child lives away from his biological parents, and their data do not allow for comparisons with the biological siblings left behind. This paper is able to address the broader question of the impact on children of fostering for potentially endogenous and exogenous reasons. This is possible because the fieldwork design collected data not just on a foster child and his host siblings, but also his left behind biological siblings. The biological siblings are a good comparison group if the fostering endogeneity operates purely at the household level, and thus is differenced out when comparing a foster child with his biological siblings.

\subsection{Identification Strategy}

In this paper, I employ two main estimation strategies, household and child fixed effects regressions, to address the endogeneity problems regarding the fostering decision discussed in the previous 
section. The household fixed effects regression, by controlling for household level unobservable factors, measures the impact of fostering on school enrollment, conditional on the household having optimized its decision of which child to send. This contrasts with the child fixed effects regression, which goes further and conditions on a given child's unobserved type.

This is the first time these strategies have been used to address the endogeneity of child fostering and the unobserved factors influencing fostering and school enrollment. If fostering is correlated with household characteristics such as wealth or network quality, which are also important determinants of school enrollment, then failing to control for these factors can yield biased estimates of the fostering impact on school enrollment. The household fixed effects regression compares the school enrollment for a foster child and the host siblings, within the same household, before and after the fostering episode, and the household fixed effect captures any time-invariant household characteristics that influence school enrollment.

The identification strategy can be illustrated using a two-by-two difference in differences table. Panel A of Table 3 shows average school enrollment rates for foster children and the host siblings they live with for the year before the fostering and the year after the fostering. The results are imprecise because not all available information is used, in particular children who were fostered in 1998 are excluded from this table. ${ }^{9}$ The cross-sectional results indicate that foster children, in the year prior to the fostering, are much less likely to be enrolled compared with the host siblings they are currently living with. Average enrollment for host siblings is 35.0 percent while only 12.4 percent of foster children are enrolled. These results are consistent with previous research that uses cross-sectional data. For both foster children and host siblings, average enrollment increased after the fostering, but it increased more for the foster children. The difference in differences result

\footnotetext{
${ }^{9}$ For households fostering a child in 1999, I use 1998 enrollment as pre-fostering enrollment and 1999 enrollment as post-fostering enrollment. For households fostering a child in 2000, I consider 1999 as pre-fostering enrollment and 2000 as post-fostering enrollment. Results in Table 3 are similar if instead I exclude the children fostered in 2000 and use enrollment in the year of fostering as pre-fostering enrollment and post-fostering enrollment is the following year.
} 
can be interpreted as the impact of fostering on enrollment under the assumption that, without the fostering episode, the change in enrollment for the two groups would not systematically differ. After the fostering, the change in enrollment for foster children is 1.8 percent higher than that of host family siblings. The result is not statistically significant, but making full use of the panel dimension of the data in the following sections yields more precise estimates.

To incorporate all available information, I use a household fixed effects regression which is comparable to the difference in differences estimator. In the simplest household fixed effects specification (additional age and gender controls are added later), I estimate the following:

$$
S_{i j t}=\beta_{0}+\gamma_{j}+\beta_{1}\left(\text { EverFostered }_{i j} * \text { AfterFostering }_{j t}\right)+\beta_{2}\left(\text { EverFostered }_{i j}\right)+\delta_{t}+\varepsilon_{i j t}
$$

where $S_{i j t}$ is the school enrollment status for child $i$ in household $j$ at time $t$, where household $j$ refers to either the host or biological household, $\gamma_{j}$ is the household fixed effect, EverFostered ${ }_{i j} *$ AfterFostering $_{j t}$ indicates the years after the fostering for the foster child, EverFostered $_{i j}$ indicates if the child is a foster child, $\delta_{t}$ are time dummies intended to capture any secular time effects in school enrollment, and $\varepsilon_{i j t}$ is a random, idiosyncratic error term. ${ }^{10}$ The coefficient $\beta_{1}$ is the effect of fostering on school enrollment for the foster child compared to the host siblings in the same household. The main identification assumption for the estimate of $\beta_{1}$ to be consistent is that any factors that influence why certain households send and receive children are captured by the $\gamma_{j}$ household fixed effect term, and these factors do not vary over time. The household fixed effects specification is identified by variation across children within the same household over time.

In addition to controlling for unobservables within the household that might be correlated with fostering and school enrollment, a related exercise would be to control for a given child's unobserved

\footnotetext{
${ }^{10}$ The secular time effects could also be captured by including an AfterFostering main effect, although that is more restrictive than including unrestricted time dummies as in the text. Both approaches yield similar results.
} 
attributes which might influence both fostering and school enrollment. In the following child fixed effects specification, I measure the impact of fostering on that child's educational enrollment, conditional on the child's unobserved attributes:

$$
S_{i j t}=\beta_{0}+\alpha_{i}+\beta_{1}\left(\text { EverFostered }_{i j} * \text { AfterFostering }_{j t}\right)+\eta_{t}+\psi_{i j t}
$$

where $S_{i j t}$ and EverFostered Ev $_{i j} *$ AfterFostering $_{j t}$ are as previously defined, $\eta_{t}$ are time dummies to capture any secular time effects in school enrollment, $\alpha_{i}$ refers to the child fixed effect, and $\psi_{i j t}$ is a random, idiosyncratic error term. ${ }^{11}$ The child fixed effects specification is identified by within child variation over time and relies on the identification assumption that any unobservable factors that influence fostering and school enrollment do not vary over time. All time-invariant factors, such as a child's ability or personality, will be captured by the fixed effects. ${ }^{12}$

While these two estimation strategies (household and child fixed effects) improve measurement of the fostering impact on school enrollment, most panel datasets are only able to compare foster children with their current host siblings and are still not able to fully measure the fostering impact. Even if the foster child is treated poorly and is worse off after the fostering relative to his new host siblings, the foster child still might be better off in terms of school enrollment relative to the treatment he would have received if he had stayed with his biological family. It is impossible to measure the "true" counterfactual that would compare the school enrollment change for the foster child if he is sent to a host family with the school enrollment change for the same foster child in the same time period if he had instead remained behind. However, with this dataset, it is possible to

\footnotetext{
${ }^{11}$ In equation 2 , I do not include the term Ever Fostered ${ }_{i j}$ because it will be absorbed by the fixed effects.

${ }^{12}$ If the source of the fostering's endogeneity is time varying, the fixed effects estimation strategy will not be able to address this problem. To deal with any time-varying unobservable factors, I tried an instrumental variables estimation strategy using household level agricultural shocks and network quality as instruments for fostering. These instruments have strong explanatory power in explaining why a household sends out a child in a given year (Akresh,

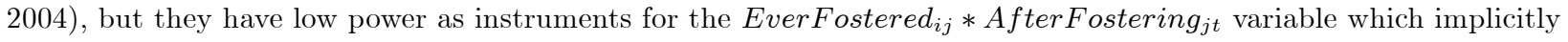
is also measuring the duration of the fostering.
} 
compare the school enrollment change for the foster child with the foster child's biological siblings who were left behind. This comparison will give a lower bound for the fostering impact, since the biological siblings who remained behind were also affected by the fostering by having more resources available to spread among fewer children and may themselves be better off after the fostering. A comparison of the biological siblings with children from non-fostering households can be used as the baseline to measure the improvement for the biological siblings relative to households that do not engage in fostering.

In Panel B of Table 3, I compare foster children before and after the fostering episode with their biological siblings who stayed behind. As in Panel A, the results are imprecise because not all available information is used, specifically children who were fostered in 1998 are excluded from this table. After the fostering, foster children have 0.8 percent higher enrollment compared to the biological siblings from the same household.

\section{Empirical Results}

\subsection{Household Fixed Effects Results}

In Panel A of Table 4, I estimate the household fixed effects regression from equation 1 comparing foster children with the host siblings they live with. ${ }^{13}$ Column 1 presents the baseline specification in which foster children are 1.5 percent more likely to be enrolled after being fostered compared to the host siblings. The coefficient is not significant, but the standard error is smaller than in Table 3, indicating foster children are unlikely to be much worse off following the fostering, with a 90 percent confidence interval ranging from a 3.3 percent drop to a 6.3 percent increase. However, foster

\footnotetext{
${ }^{13}$ All households that fostered a child in 1998, 1999, or 2000 are included in the regressions. There are 2682 observations which consists of 640 host siblings and 316 foster children measured over 3 years minus 186 observations that were excluded because the child is under age 5 in a given year.
} 
children come from households that have 19.6 percent lower enrollment rates, which is consistent with previous results in which receiving households are shown to be better off (Akresh, 2004). Controlling for the gender of the child indicates boys are 2.8 percent more likely to be enrolled than girls. In all of the regressions, to capture any level effect on enrollment due to a child's age, I include dummy variables for each age. All the regressions in this table also include year dummies intended to capture secular time trends in school enrollment.

In column 2, I analyze whether the fostering impact varies based on the child's gender by including an interaction of the variable Ever Fostered E $_{i j} *$ After Fostering $_{j t}$ with a variable indicating if the child is male. Foster boys are 6.1 percent more likely to be enrolled than foster girls, yet this difference is not significant. Column 3 measures whether the fostering impact varies based on the child's age by including an interaction of the variable EverFostered Ev $_{i j} *$ After Fostering $_{j t}$ with age variables indicating if the child was young (aged 5,6, or 7), middle (aged 8 to 11), or old (over age 12). Young foster children are 18.4 percent more likely to be enrolled after the fostering relative to older foster children, and the coefficient is statistically significant at the 5 percent level. Children aged eight to eleven are 10.0 percent more likely to be enrolled after the fostering compared to older foster children, but the coefficient is not significant at standard levels (t-statistic is 1.54). These results indicate that for certain children, fostering is a strong positive experience (at least in terms of school enrollment), while for other children (in particular older children), the results are more mixed and potentially negative.

Panel B of Table 4 presents household fixed effects regressions comparing foster children with their biological siblings. The regression in column 4 indicates foster children are 3.6 percent more likely to be enrolled after the fostering than the biological siblings who remained behind. This is evidence that while foster children may not be better off compared to their host siblings (column 1), they are more likely to be enrolled after the fostering compared to their biological siblings. Column 
5 estimates the regression including a gender and fostering interaction, while column 6 includes an age and fostering interaction. Both foster girls and boys do better after the fostering relative to the biological siblings remaining behind, but foster boys are 5.6 percent more likely to be enrolled than foster girls, yet this difference is not significant. Relative to their biological siblings, young foster children are 12.7 percent more likely to be enrolled after the fostering than older foster children. ${ }^{14}$

I further explore the heterogeneity in observed outcomes for foster children in Table 5 in which I present household fixed effects regressions broken down by the reason for the fostering and the location of the sending and receiving households. In Panel A, I compare foster children with their host siblings, and in Panel B, I compare foster children with their biological siblings. Only the coefficient on the term EverFostered $i j *$ AfterFostering $_{j t}$ is presented, although all regressions also include control variables indicating age, gender, year, and if the child was ever fostered. Column 1 repeats the previous results from Table 4, columns 1 and 4.

For each foster child, the head of the biological household answered why the child was sent to live with another family. Based on those responses, if the foster child is sent for schooling reasons, then after being fostered the child is 36.2 and 35.3 percent more likely to be enrolled compared with his host and biological siblings, respectively. This result contrasts with a foster child sent for child labor reasons. These children are 6.4 and 2.5 percent less likely to be enrolled after the fostering compared with their host and biological siblings, respectively, although the result is only significant when compared to the host siblings. Children fostered due to a parent's death are significantly better off compared to the biological siblings left behind, with enrollment 16.9 percent higher after

\footnotetext{
${ }^{14}$ Appendix Table 1 presents household fixed effects regressions comparing the host and biological siblings from a paired sending and receiving household, in which the household fixed effect is for the joint sender-receiver paired household. Biological siblings are slightly worse off after the fostering compared with host siblings, but the result is not statistically significant. However, in the case of children fostered due to a parent's death (column 6), the biological siblings are significantly worse off, with 16.0 percent lower enrollment after the fostering compared to the host siblings. Likewise, when foster children are sent to households living in the same village, the biological siblings are 8.4 percent less likely to be enrolled after the fostering compared with the host siblings.
} 
the fostering.

There is evidence that where the foster child is sent is correlated with how well that child does relative to the child's host and biological siblings. Foster children sent to live with households in Côte d'Ivoire or Ouagadougou are 11.6 and 9.3 percent more likely to be enrolled after the fostering compared with, respectively, their host and biological siblings. This result contrasts with the outcome for foster children sent to households living in the same village, which is more likely to occur following a parent death. These foster children are 14.3 percent less likely to be enrolled after the fostering compared with their host siblings.

\subsection{Child Fixed Effects Results}

In using the household fixed effects specification, I can address the issue that certain households are more prone to foster children than other households and that these unobservable factors influencing fostering might also affect school enrollment. However, there might also be factors (unobservable to the econometrician) at the child level that influence the fostering decision and that child's school enrollment. These factors could include the child's ability or personality (which are probably known by the biological parents) and would bias the measurement of the impact of fostering on school enrollment. A child fixed effects regression can control for these factors and measure the impact on school enrollment after that child is fostered.

In Table 6, I present results from child fixed effects regressions comparing foster children with host siblings (Panel A) and biological siblings (Panel B). After controlling for the foster child's type, there is no impact of fostering on the foster child's school enrollment relative to either host (column 1) or biological siblings (column 4). Foster boys are 4.2 and 3.9 percent more likely to be enrolled after the fostering compared to host and biological siblings, respectively, but the coefficients are not significant. Similar to the household fixed effects, younger foster children do better than older 
foster children relative to either host or biological siblings. Results in columns 3 and 6 show that younger foster children are 12.0 and 11.8 percent more likely to be enrolled after the fostering exchange compared to host and biological siblings, respectively.

These results indicate that, after conditioning on the child's type, there are no longer any positive enrollment impacts following the fostering, with the exception of younger foster children. This provides evidence that the biological parents, in selecting which child to send out, are probably taking into account these factors that are unobservable to the researcher yet clearly influence how the foster child fares in the host household. Even after controlling for the child's type, the impact of fostering, while not positive, is still not negative as many individuals believe.

\subsection{Comparisons with Children of Non-Fostering Households}

Comparing foster children with their host and biological siblings is important, but it is also necessary to compare them with children from non-fostering households in order to understand the benefit to families of being able to reallocate resources by sending away children. Table 7 presents an overview for children from non-fostering households with information similar to Tables 1, 2, and 3. In Panels A and B, these children appear similar to the biological siblings, with an average enrollment rate of 18.3 percent, an average age of 9.4 years, and a school enrollment transition rate in which 76.4 percent of them are not enrolled in either year and 2.8 percent discontinued enrollment in 2000 . Panel C presents difference in differences results comparing foster children with children from nonfostering households using pre and post-fostering enrollment for the foster children and 1999 and 2000 enrollment for the other children, with similar results using 1998 and 1999 enrollment for these other children. There is no statistical difference between foster children and children from non-fostering households in terms of enrollment after foster children are sent away, but again the table does not use all available information and is presented only as a comparison to Table 3 . 
The child and household fixed effects specifications in Table 8 provide evidence that child fostering can lead to a Pareto improvement in school enrollment for all children involved: the host siblings in the receiving family, the biological siblings remaining behind in the sending family, and the foster child. This Pareto improvement is largest for the youngest children. The dataset used in Table 8 contains observations from 640 host siblings, 994 biological siblings, 316 foster children and 470 children from non-fostering households measured over 3 years, with the reference group in the regressions being the children from the non-fostering households.

In column 1, I control for the child's type in a child fixed effects regression and find that the host siblings, biological siblings, and foster children are, respectively, 1.9, 1.2, and 1.1 percent more likely to be enrolled after the fostering compared to children from non-fostering households. The regression controls for age effects by including dummy variables indicating if the child is young or middle aged, but in this regression in which children of all ages are pooled together, the coefficients are not statistically significant. The coefficient estimates for host siblings, biological siblings, and foster children in column 1 are roughly equal which is consistent with the child fixed effects results in Table 6, where foster children are no better off following the fostering relative to either host or biological siblings.

The earlier tables showed age was significantly correlated with enrollment outcomes for these children, and in columns 2, 3, and 4, I estimate child fixed effects regressions for subsets of children. For households that exchange a young child, the results indicate that relative to non-fostering household children, all young children are much better off after the fostering. Host siblings increase enrollment by 23.9 percent, biological siblings by 11.3 percent, and foster children by 21.5 percent relative to the non-fostering household children, and all coefficients are significant at the 1 percent level. For older children aged 8 to 11, the positive impact of fostering relative to children from non-fostering households diminishes, with biological siblings' enrollment increasing by 4.1 percent 
and host siblings having a positive but insignificant enrollment increase. Foster children aged 8 to 11 actually experience a significant 5.6 percent drop in enrollment after the fostering relative to the non-fostering household children. The oldest children in the fostering households fare the worst relative to the non-fostering household children, with host and biological siblings experiencing a 9.4 and 5.4 percent drop, respectively, in enrollment after the fostering. The older foster children experience an insignificant negative drop in enrollment relative to the non-fostering household children. Based on the child fixed effects results, on average all children in the households involved in fostering experience an improvement in enrollment, but the effect is significant and largest for the youngest children.

Columns 5 to 8 estimate household fixed effects regressions that control for time-invariant factors that might influence which households are involved in fostering children. In the regression using all children, those fostered have 4.1 percent higher enrollment than the children from non-fostering households, but the coefficient is not significant at standard levels. However, young foster children have a larger increase in enrollment, 18.2 percent, after the fostering relative to non-fostering household children, and the coefficient is significant at the 1 percent level. For older foster children, there is no significant impact after the fostering. For the host and biological siblings, the regression pooling all ages shows no impact on enrollment after the fostering, but older biological siblings are 5.8 percent less likely to be enrolled. The coefficient estimates for host siblings, biological siblings, and foster children in column 5 are consistent with the Table 4 results showing foster children to have a higher enrollment after the fostering relative to the host and biological siblings.

\subsection{Adult Welfare Outcomes}

Having provided evidence that child fostering can lead to a Pareto improvement in school enrollment

for the children in both the sending and receiving households, it is also important to understand if 
fostering only has a short-run impact or if the effects are long-lasting and translate into other social welfare gains for the fostered individual. In addition to the tracking component in the fieldwork, a unique aspect of the data is that they contain information about the childhood fostering experience for every current adult head of household who was interviewed. Results in Table 9 indicate a strong positive correlation between current wealth and the survey respondent having been fostered as a child. ${ }^{15}$ Results in columns 1 and 4 show that respondents who were fostered as children have 40.1 percent higher asset levels and 54.3 percent higher income levels (calculated after converting log points into percentage increases).

I do not claim that fostering causes higher wealth because there could be other factors that influence the respondent's wealth such as gender, education, and family background. In columns 2 and 5, I estimate ordinary least squares regressions to measure the impact of being fostered as a child on current wealth, controlling for observable factors that might influence current wealth including whether the respondent's father or mother held a position of responsibility in the village, the number of the father's wives, the respondent's marital status, age, occupation, education and gender. The point estimate on the fostering variable is reduced slightly compared with columns 1 and 4, but there is still a positive, significant correlation between being fostered as a child and higher current wealth levels.

Columns 3 and 6 measure the impact of being fostered as a child for various durations and show that children who spent less than 5 years living away from their biological parents have higher levels of current wealth compared with non-fostered children (71.9 percent higher in assets and 59.7 percent higher in income). For those children who lived away from their biological parents for a longer time period, the positive correlation with current wealth diminishes. This is consistent

\footnotetext{
${ }^{15}$ I use two measures of current wealth, the average value of all assets owned between 1998 and 2000 and the average level of income over the same time period. Assets include seventeen different items that rural households might typically own, such as a bicycle, a radio, a wheelbarrow and a cart. To account for heterogeneity in asset quality across individuals, the value of each asset as reported by the respondent is used to measure total asset value.
} 
with previous research that shows households use fostering as a transitory risk-coping strategy in response to negative, exogenous income shocks (Akresh, 2004). It is possible that for children with longer fostering durations, the biological parents never recovered from the transitory shock and this explains the child's lower current wealth levels.

Despite controlling for observables that might influence current wealth, foster status as a child could still be endogenous with unobservable factors correlated with fostering status and wealth biasing the regression estimates. For example, certain households might have better quality social networks and be more likely to foster a child and that child could have higher current wealth not because of being fostered as a child, but because of the parent's better social network. To address this endogeneity, I use information about the childhood fostering status of each of the respondent's biological siblings. In addition, the respondents provided information about the education, occupation, and location for each of his siblings. I can therefore estimate a household fixed effects regression which compares the welfare outcomes for siblings who were fostered as children with the welfare outcomes of siblings from the same family who were not fostered as children. The evidence in Table 10 indicates that those siblings who were fostered as children are 9.9 percent more likely to have attended school, are 16.6 percent more likely to have a "good" occupation with higher earnings such as a businessman, government employee, teacher, or manual laborer, are 10.7 percent less likely to be farmers, and are 10.0 percent less likely to live in a rural village.

The data do not contain information about current assets or income for each of the siblings, so it is not possible to replicate the OLS regressions from Table 9 using the household fixed effects estimation strategy. To compare the household fixed effects and OLS results using the same dependent variables, in columns $1,3,5$, and 7 , I present OLS estimates measuring the impact of being fostered as a child on education, having a "good" job, being a farmer, and living in a rural area. The OLS point estimates are similar in sign and significance but are larger in magnitude. 


\section{Conclusion}

Given previous research that details the negative implications for African children living away from their biological parents, the results of this paper are somewhat surprising. This paper systematically

analyzes the school enrollment outcomes of children living away from their parents and finds a Pareto improvement in school enrollment due to the institution of fostering and a household's ability to adjust its structure. On average, all children in the households involved in fostering (host siblings in the receiving household, biological siblings in the sending household, and the foster child) experience an increase in school enrollment relative to children from non-fostering households, and this impact is largest for the youngest children.

For economists who often assume there should be gains from trade between willing parties, these results should not be viewed with surprise. Two households that choose to reallocate resources by sending a child from the biological parents to the host family would only do so if there was the expectation of an improvement in each household's welfare. The host household would be unlikely to receive a child if that was going to make them worse off, and likewise, the sending household would not send a child if that was going to make them worse off. I find that not only are the two households not worse off, but they actually experience an improvement in their children's school enrollment. This has significant policy implications for international development organizations who are currently trying to prevent children from growing up away from their biological parents.

These results about the impact of a household adjusting its structure have implications for the larger issue in Africa and even the United States of how to define a household and what is the appropriate unit of analysis for studying the impact on a child's welfare outcomes. A large literature in the United States analyzes the schooling and health outcomes of children who live in non-traditional household structures and generally finds that not having the biological mother 
present is detrimental to the welfare outcomes of the child (McLanahan and Sandefur, 1994; Case and Paxson, 2001; Ginther and Pollak, 2003). This paper finds substantially different outcomes for children from rural Burkina Faso. The results are based on an estimation strategy, household and child fixed effects, that can address the endogeneity of fostering. This paper also describes the advantages of a research methodology, tracking both households involved in the fostering exchange, without which I could not examine the impact of fostering on the biological siblings who were left behind.

This analysis is informative for understanding why families choose to adjust their structure and reallocate resources between two households (sender and receiver) in such a way as to make everyone better off in terms of school enrollment. However, while there is strong evidence of a short-run Pareto improvement in schooling for all children associated with fostering and a longrun improvement in the welfare outcomes for the foster child, future research needs to examine additional welfare measures to see if fostering also has a positive impact along other dimensions, such as health and nutrition. 


\section{References}

Ainsworth, Martha. 1996. "Economic Aspects of Child Fostering in Côte d'Ivoire." In Research in Population Economics, Vol. 8. Editor T. Paul Schultz. JAI Press Inc.

Ainsworth, Martha, Kathleen Beegle and Godlike Koda. 2002. "The Impact of Adult Mortality on Primary School Enrollment in Northwestern Tanzania." Africa Region Human Development Working Paper, World Bank.

Ainsworth, Martha and Deon Filmer. 2002. "Poverty, AIDS, and Children's Schooling: A Targeting Dilemma." World Bank Policy Research Working Paper 2885.

Akresh, Richard. 2004. "Risk, Network Quality, and Family Structure: Child Fostering Decisions in Burkina Faso." BREAD Working Paper No. 65.

Akresh, Richard. 2004b. "Survey and Tracking Methodology, Fieldwork Definitions, and Project Overview." Yale University, Ph.D. Dissertation, Chapter 2.

Bishai, David, El Daw Suliman, Heena Brahmbhatt, Fred Wabwire-Mangen, Godfrey Kigozi, Nelson Sewankambo, David Serwadda, Maria Wawer, Ron Gray. 2003. "Does Biological Relatedness Affect Survival?" Demographic Research, Volume 8, Article 9.

Bledsoe, Caroline and Anastasia Brandon. 1989. "Le Placement des Enfants et Son Influence sur la Mortalité." In Mortalité et Société en Afrique au Sud du Sahara. Editors Gilles Pison, Etienne van de Walle and Mpembele Sala-Diakanda. Institut National d'Etudes Demographiques (INED). Presses Universitaires de France, Paris, France.

Case, Anne, I-Fen Lin and Sara McLanahan. 2000. "How Hungry is the Selfish Gene?" Economic Journal, 110(466), 781-804.

Case, Anne and Christina Paxson. 2001. "Mothers and Others: Who Invests in Children's Health?" Journal of Health Economics, 20(3), 301-328.

Case, Anne, Christina Paxson, and Joseph Ableidinger. 2004. "Orphans in Africa: Parental Death, Poverty, and School Enrollment." Demography, 41(3), 483-508.

Castle, Sarah E. 1995. "Child Fostering and Children's Nutritional Outcomes in Rural Mali: The Role of Female Status in Directing Child Transfers." Social Science and Medicine, 40(5), 679-693.

Cichello, Paul L. 2004. "Child Fostering and Human Capital Formation in KwaZulu-Natal: An Economist's Perspective." Social Dynamics, 29(2).

Eloundou-Enyegue, Parfait M. and David Shapiro. 2004. "Are African Families Becoming Overextended? A Historical Analysis of the Effects of Family Extension on Schooling Inequalities in Cameroon." Paper presented at 2004 Population Association of America Annual Meetings, Boston, MA.

Evans, David and Edward Miguel. 2004. "Orphans and Schooling in Africa: A Longitudinal Analysis." BREAD Working Paper No. 56.

Fafchamps, Marcel and Jackline Wahba. 2004. "Child Labor, Urban Proximity, and Household Composition." University of Oxford, manuscript. 
Gertler, Paul, David Levine and Minnie Ames. 2004. "Schooling and Parent Death." Review of Economics and Statistics, 86(1), 211-225.

Ginther, Donna K. and Robert A. Pollak. 2003. "Does Family Structure Affect Children's Educational Outcomes?" NBER Working Paper 9628.

Haddad, Lawrence and John Hoddinott. 1994. "Household Resource Allocation in the Côte d'Ivoire: Inferences from Expenditure Data." In Poverty, Inequality, and Rural Development. Editors T. Lloyd and O. Morrissey. St. Martin's Press, New York.

Isiugo-Abanihe, Uche. 1985. "Child Fosterage in West Africa." Population and Development Review, 11(1), 53-73.

Kielland, Anne. 1999. "Children's Work in Benin: Estimating the Magnitude of Exploitative Child Placement." Manuscript, World Bank, Social Protection Sector.

Lloyd, Cynthia B. and Ann K. Blanc. 1996. "Children's Schooling in sub-Saharan Africa: The Role of Fathers, Mothers, and Others." Population and Development Review, 22(2), 265-298.

McLanahan, Sara and Gary Sandefur. 1994. Growing Up with a Single Parent: What Hurts, What Helps. Harvard University Press, Cambridge, MA.

Page, Hilary J. 1989. "Childbearing vs. Childrearing: Coresidence of Mother and Child in subSaharan Africa." In Reproduction and Social Organization in Sub-Saharan Africa. Editor Ron J. Lesthaeghe. University of California Press, Berkeley, CA.

Serra, Renata. 2003. "Child Fostering in Africa: Can Labor and Schooling Motives Coexist?" Cambridge University, manuscript.

Thomas, Duncan, Kathleen Beegle, Elizabeth Frankenberg, Bondan Sikoki, John Strauss and Graciela Teruel. 2004. "Education in a Crisis." Journal of Development Economics, 74(1), $53-85$.

UNICEF. 1999. "Child Domestic Work." Innoncenti Digest, no. 5. International Child Development Center. Florence, Italy.

Vandermeersch, Céline. 2002. "Child Fostering Under Six in Senegal in 1992-1993." PopulationEnglish, 57(4-5), 659-686.

World Bank. 2003. Achieving Universal Primary Education by 2015: A Chance for Every Child. Editors Barbara Bruns, Alain Mingat, and Ramahatra Rakotomalala. Washington, D.C.

Yamano, Takashi, and T.S. Jayne. 2004. "Working-Age Adult Mortality and Primary School Attendance in Rural Kenya." Tegemeo Institute of Agricultural Policy and Development, Working Paper No 5 .

Zimmerman, Frederick J. 2003. "Cinderella Goes to School: The Effects of Child Fostering on School Enrollment in South Africa." Journal of Human Resources, 38(3), 557-590. 
Table 1: Summary Statistics Comparing Foster Children, Host Siblings, and Biological Siblings

\begin{tabular}{llll}
\hline \hline & $\begin{array}{l}(1) \\
\text { Host } \\
\text { Siblings }\end{array}$ & $\begin{array}{l}\text { (2) } \\
\text { Foster } \\
\text { Children }\end{array}$ & $\begin{array}{l}\text { (3) } \\
\text { Biological } \\
\text { Siblings }\end{array}$ \\
\hline Enrollment Rate (\% currently enrolled) & 31.1 & 17.6 & 19.5 \\
Average Age & 10.1 & 10.4 & 9.7 \\
Median Age & 10 & 10 & 9 \\
Percentage Male & 55.6 & 37.0 & 50.7 \\
\hline Number of Children & 640 & 316 & 994 \\
\hline
\end{tabular}

Note: All summary statistics exclude those observations in which the child is under age 5 in a given year. Data source: Author's survey. 
Table 2: Tabulation of School Enrollment Transitions (Before and After Fostering Episode) Comparing Foster Children, Host Siblings, and Biological Siblings (Column Percent)

\begin{tabular}{|c|c|c|c|}
\hline $\begin{array}{l}\text { School Enrollment Transitions } \\
\text { Column \% } \\
\text { (N) }\end{array}$ & $\begin{array}{l}\text { (1) } \\
\text { Host Siblings }\end{array}$ & $\begin{array}{l}\text { (2) } \\
\text { Foster Children }\end{array}$ & $\begin{array}{l}\text { (3) } \\
\text { Biological Siblings }\end{array}$ \\
\hline Never enrolled (Not enrolled before, Not enrolled after) & $\begin{array}{l}60.5 \\
(204)\end{array}$ & $\begin{array}{l}82.7 \\
(167)\end{array}$ & $\begin{array}{l}77.9 \\
(468)\end{array}$ \\
\hline Discontinued Enrollment (Enrolled before, Not enrolled after) & $\begin{array}{l}3.3 \\
(11)\end{array}$ & $\begin{array}{l}2.0 \\
(4)\end{array}$ & $\begin{array}{l}2.3 \\
(14)\end{array}$ \\
\hline Newly Enrolled (Not enrolled before, Enrolled after) & $\begin{array}{l}4.5 \\
(15)\end{array}$ & $\begin{array}{l}4.9 \\
(10)\end{array}$ & $\begin{array}{l}4.5 \\
(27)\end{array}$ \\
\hline Enrolled both years (Enrolled before, Enrolled after) & $\begin{array}{l}31.7 \\
(107)\end{array}$ & $\begin{array}{l}10.4 \\
(21)\end{array}$ & $\begin{array}{l}15.3 \\
(92)\end{array}$ \\
\hline Observations & 337 & 202 & 601 \\
\hline $\begin{array}{l}\text { Testing for equality of all } 3 \text { columns: } \\
\text { Testing for equality of columns } 1 \& 2 \text { : } \\
\text { Testing for equality of columns } 1 \& 3 \text { : } \\
\text { Testing for equality of columns } 2 \& 3 \text { : }\end{array}$ & $\begin{array}{l}\chi^{2}(6)=51.00 \\
\chi^{2}(3)=37.11 \\
\chi_{2}^{2}(3)=36.22 \\
\chi^{2}(3)=3.36\end{array}$ & \multicolumn{2}{|c|}{$\begin{array}{l}\text { p-value }=0.00 \\
\text { p-value }=0.00 \\
\text { p-value }=0.00 \\
\text { p-value }=0.34\end{array}$} \\
\hline
\end{tabular}

Note: I restrict the table to households that fostered in 1999 and 2000 because of the need for enrollment information prior to the fostering episode. There are 244 host siblings, 108 foster children, and 310 biological siblings that were fostered in 1998 that are excluded from the table. All results also exclude children under age 5. There were 59 host siblings, 6 foster children, and 83 biological siblings under age 5 in the year prior to fostering who were also excluded from the regressions. For households fostering in 1999, I consider 1998 enrollment as prior enrollment and 1999 enrollment as after. Results are similar if instead I focus on households involved in fostering in 1998 and 1999 and, for households fostering in 1998 use 1998 enrollment as before and 1999 enrollment as after. Testing for the equality of all 3 columns yields a LR $\chi^{2}$ (6) test statistic of 51.00 with the corresponding $p$-value of 0.00 . Testing for the equality of columns 1 and 2 yields a LR $\chi^{2}(3)$ test statistic of 37.11 with a p-value of 0.00 . Testing for the equality of columns 1 and 3 yields a LR $\chi^{2}(3)$ test statistic of 36.22 with a p-value of 0.00 . Finally, testing for the equality of columns 2 and 3 yields a LR $\chi^{2}(3)$ test statistic of 3.36 with a p-value equal to 0.34 . Data source: Author's survey. 
Table 3: Difference in Differences Comparing Average School Enrollment for Foster Children with Host Siblings and Biological Siblings

\begin{tabular}{lrr|r}
\hline \hline Panel A: & & & \\
& & & \\
& Foster Children & Host Siblings & Difference \\
& $(\mathrm{N}=202)$ & $(\mathrm{N}=337)$ & \\
\hline Pre-Fostering & 0.124 & 0.350 & -0.226 \\
& {$[0.023]$} & {$[0.026]$} & {$[0.039]$} \\
Post-Fostering & 0.154 & 0.362 & -0.208 \\
& {$[0.025]$} & {$[0.026]$} & {$[0.039]$} \\
& & & \\
\hline Difference & 0.030 & 0.012 & 0.018 \\
& {$[0.034]$} & {$[0.033]$} & {$[0.055]$}
\end{tabular}

Panel B:

\begin{tabular}{lrr|r} 
& Foster Children & Biological Siblings & Difference \\
& $(\mathrm{N}=202)$ & $(\mathrm{N}=601)$ & \\
\hline Pre-Fostering & 0.124 & 0.176 & -0.052 \\
& {$[0.023]$} & {$[0.016]$} & {$[0.031]$} \\
Post-Fostering & & & \\
& 0.154 & 0.198 & -0.044 \\
& {$[0.025]$} & {$[0.016]$} & {$[0.032]$} \\
\hline Difference & 0.030 & 0.022 & 0.008 \\
& {$[0.034]$} & {$[0.022]$} & {$[0.044]$} \\
\hline
\end{tabular}

Note: Standard errors in brackets. I restrict the table to only households involved in fostering in 1999 and 2000 because of the need for enrollment information prior to the fostering episode. For households fostering in 1999, I consider 1998 enrollment as prefostering enrollment and 1999 enrollment as post-fostering. For households fostering in 2000, 1999 is pre-fostering enrollment and 2000 is post-fostering enrollment. Results are similar if instead I exclude the children fostered in 2000 and use enrollment in the year of fostering as pre-fostering enrollment and post-fostering enrollment is the following year. Only children 5 years and older are included in this table. Data source: Author's survey. 
Table 4: Household Fixed Effects Estimation Comparing School Enrollment of Foster Children with Host Siblings and Foster Children with Biological Siblings

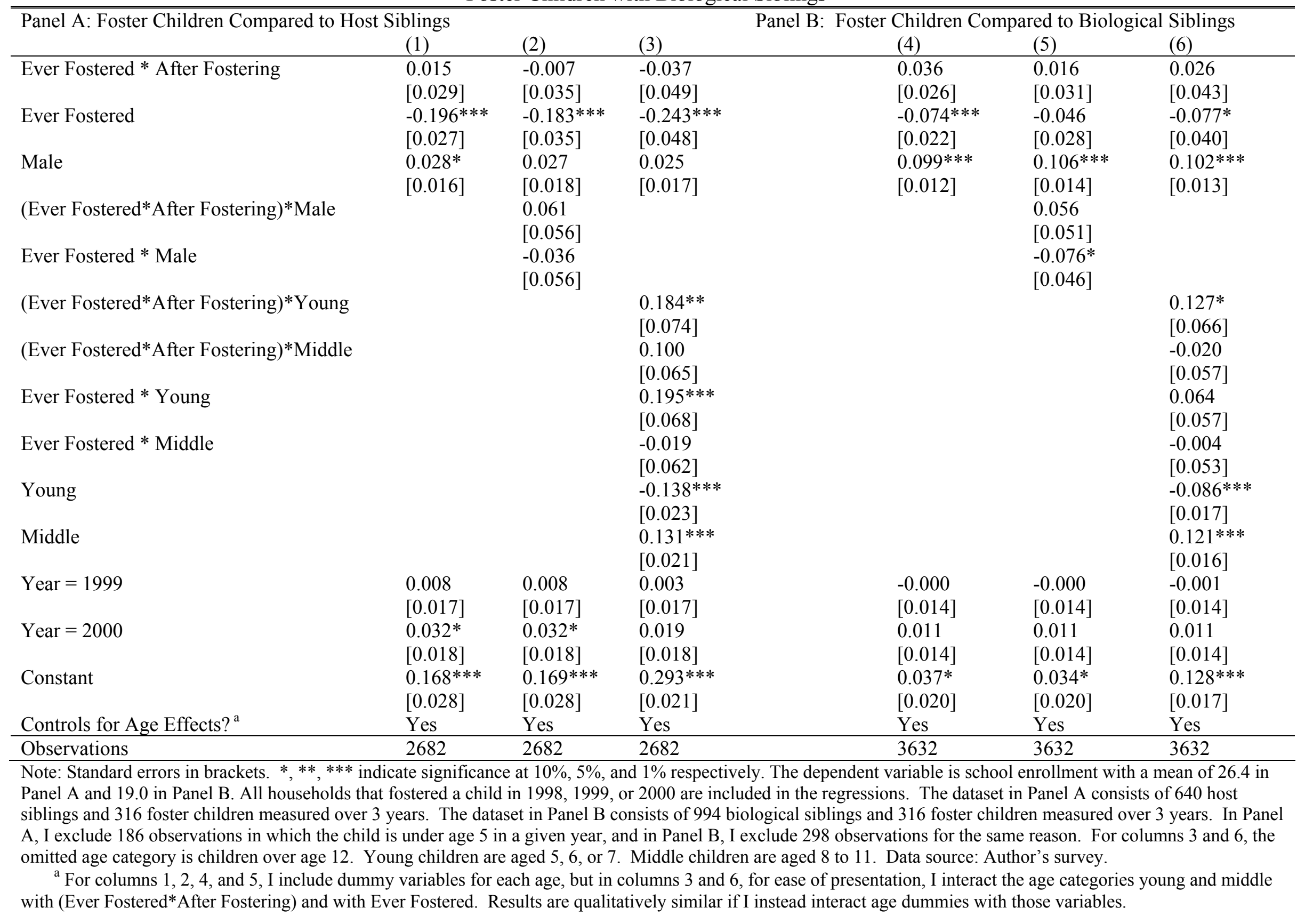


Table 5: Household Fixed Effects Estimation Comparing Foster Children with Host Siblings and Foster Children with Biological Siblings

\begin{tabular}{|c|c|c|c|c|c|c|}
\hline & $\begin{array}{l}\text { (1) } \\
\text { All } \\
\text { Households }\end{array}$ & $\begin{array}{l}(2) \\
\text { Only } \\
\text { Households } \\
\text { Fostering for } \\
\text { Schooling } \\
\text { Reasons }\end{array}$ & $\begin{array}{l}(3) \\
\text { Only } \\
\text { Households } \\
\text { Fostering for } \\
\text { Child Labor } \\
\text { Reasons }\end{array}$ & $\begin{array}{l}(4) \\
\text { Only } \\
\text { Households } \\
\text { Fostering due } \\
\text { to Parent } \\
\text { Death } \\
\end{array}$ & $\begin{array}{l}\text { (5) } \\
\text { Only Households } \\
\text { Fostering To \& } \\
\text { From Cote } \\
\text { d'Ivoire / } \\
\text { Ouagadougou } \\
\end{array}$ & $\begin{array}{l}\text { (6) } \\
\text { Only } \\
\text { Households } \\
\text { Fostering } \\
\text { Within Same } \\
\text { Village }\end{array}$ \\
\hline \multicolumn{7}{|c|}{ Panel A: Foster Children Compared to Host Siblings } \\
\hline Ever Fostered $*$ After Fostering & $\begin{array}{l}0.015 \\
{[0.029]}\end{array}$ & $\begin{array}{l}0.362 * * * \\
{[0.109]}\end{array}$ & $\begin{array}{l}-0.064 * \\
{[0.037]}\end{array}$ & $\begin{array}{l}0.063 \\
{[0.103]}\end{array}$ & $\begin{array}{l}0.116 * * \\
{[0.052]}\end{array}$ & $\begin{array}{l}-0.143 * \\
{[0.081]}\end{array}$ \\
\hline Observations & 2682 & 327 & 1332 & 278 & 861 & 382 \\
\hline Number of Households & 316 & 32 & 193 & 23 & 106 & 57 \\
\hline \multicolumn{7}{|c|}{ Panel B: Foster Children Compared to Biological Siblings } \\
\hline Ever Fostered $*$ After Fostering & $\begin{array}{l}0.036 \\
{[0.026]}\end{array}$ & $\begin{array}{l}0.353^{* * *} \\
{[0.100]}\end{array}$ & $\begin{array}{l}-0.025 \\
{[0.031]}\end{array}$ & $\begin{array}{l}0.169 * \\
{[0.098]}\end{array}$ & $\begin{array}{l}0.093 * * \\
{[0.046]}\end{array}$ & $\begin{array}{l}-0.003 \\
{[0.063]}\end{array}$ \\
\hline Observations & 3632 & 248 & 2366 & 208 & 1139 & 588 \\
\hline Number of Households & 316 & 32 & 193 & 23 & 106 & 57 \\
\hline
\end{tabular}

Note: Standard errors in brackets. $*, * *, * *$ indicate significance at $10 \%, 5 \%$, and $1 \%$ respectively. Each regression also includes control variables indicating age, gender, year, and if the child was ever fostered. Panel A, column 1 is copied from Table 4, column 1, and Panel B, column 1 is copied from Table 4, column 4. All households that fostered a child in 1998, 1999, or 2000 are included in the regressions. The dataset in Panel A consists of 640 host siblings and 316 foster children measured over 3 years. The dataset in Panel B consists of 994 biological siblings and 316 foster children measured over 3 years. In Panel A, I exclude 186 observations in which the child is under age 5 in a given year, and in Panel B, I exclude 298 observations for the same reason. Data source: Author's survey. 
Table 6: Child Fixed Effects Estimation Comparing Foster Children with Host Siblings and Foster Children with Biological Siblings

\begin{tabular}{|c|c|c|c|c|c|c|}
\hline \multicolumn{2}{|c|}{$\begin{array}{l}\text { Panel A: Foster Children Compared to Host Siblings } \\
\text { (1) }\end{array}$} & $(2)$ & $(3)$ & \multicolumn{3}{|c|}{$\begin{array}{l}\text { Panel B: Foster Children Compared to Biological Siblings } \\
\begin{array}{lll}(4) & (5) & \text { (6) }\end{array}\end{array}$} \\
\hline Ever Fostered $*$ After Fostering & $\begin{array}{l}-0.006 \\
{[0.018]}\end{array}$ & $\begin{array}{l}-0.021 \\
{[0.022]}\end{array}$ & $\begin{array}{l}-0.046^{*} \\
{[0.025]}\end{array}$ & $\begin{array}{l}0.001 \\
{[0.018]}\end{array}$ & $\begin{array}{l}-0.013 \\
{[0.022]}\end{array}$ & $\begin{array}{l}-0.042 * \\
{[0.024]}\end{array}$ \\
\hline (Ever Fostered*After Fostering)*Male & & $\begin{array}{l}0.042 \\
{[0.034]}\end{array}$ & & & $\begin{array}{l}0.039 \\
{[0.035]}\end{array}$ & \\
\hline (Ever Fostered*After Fostering)*Young & & & $\begin{array}{l}0.120 * * * \\
{[0.041]}\end{array}$ & & & $\begin{array}{l}0.118 * * * \\
{[0.041]}\end{array}$ \\
\hline (Ever Fostered*After Fostering)*Middle & & & $\begin{array}{l}0.040 \\
{[0.028]}\end{array}$ & & & $\begin{array}{l}0.039 \\
{[0.028]}\end{array}$ \\
\hline Year $=1999$ & $\begin{array}{l}0.004 \\
{[0.010]}\end{array}$ & $\begin{array}{l}0.004 \\
{[0.010]}\end{array}$ & $\begin{array}{l}0.019 * \\
{[0.010]}\end{array}$ & $\begin{array}{l}0.001 \\
{[0.009]}\end{array}$ & $\begin{array}{l}0.001 \\
{[0.009]}\end{array}$ & $\begin{array}{l}0.018 * * \\
{[0.009]}\end{array}$ \\
\hline Year $=2000$ & $\begin{array}{l}0.024 * * \\
{[0.012]}\end{array}$ & $\begin{array}{l}0.023 * * \\
{[0.012]}\end{array}$ & $\begin{array}{l}0.053 * * * \\
{[0.011]}\end{array}$ & $\begin{array}{l}0.016 \\
{[0.011]}\end{array}$ & $\begin{array}{l}0.016 \\
{[0.011]}\end{array}$ & $\begin{array}{l}0.049 * * * \\
{[0.009]}\end{array}$ \\
\hline Constant & $\begin{array}{l}0.113 * * * \\
{[0.019]}\end{array}$ & $\begin{array}{l}0.112 * * * \\
{[0.019]}\end{array}$ & $\begin{array}{l}0.241 * * * \\
{[0.007]}\end{array}$ & $\begin{array}{l}0.060 * * * \\
{[0.016]}\end{array}$ & $\begin{array}{l}0.060 * * * \\
{[0.016]}\end{array}$ & $\begin{array}{l}0.167 * * * \\
{[0.006]}\end{array}$ \\
\hline Controls for Age Effects? ${ }^{\mathrm{a}}$ & Yes & Yes & Yes & Yes & Yes & Yes \\
\hline Observations & 2682 & 2682 & 2682 & 3632 & 3632 & 3632 \\
\hline Number of Children & 956 & 956 & 956 & 1310 & 1310 & 1310 \\
\hline
\end{tabular}

Note: Standard errors in brackets. $*, * *, * *$ indicate significance at $10 \%, 5 \%$, and $1 \%$ respectively. The dependent variable is school enrollment with a mean of 26.4 in Panel A and 19.0 in Panel B. All households that fostered a child in 1998, 1999, or 2000 are included in the regressions. The dataset in Panel A consists of 640 host household siblings and 316 foster children measured over 3 years. The dataset in Panel B consists of 994 biological siblings and 316 foster children measured over 3 years. In Panel A, I exclude 186 observations in which the child is under age 5 in a given year, and in Panel B, I exclude 298 observations for the same reason. For columns 3 and 6, the omitted age category is children over age 12. Young children are aged 5,6 , or 7. Middle children are aged 8 to 11. Data source: Author's survey.

${ }^{\text {a }}$ For columns 1, 2, 4, and 5, I include dummy variables for each age, but in columns 3 and 6, for ease of presentation, I interact the age categories young and middle with (Ever Fostered*After Fostering). Results are qualitatively similar if I instead interact age dummies with that variable. 
Table 7: Overview for Children of Non-Fostering Households

\begin{tabular}{|c|c|c|c|}
\hline \multirow[t]{3}{*}{ Panel A: Summary Statistics } & \multicolumn{3}{|c|}{ Panel B: School Enrollment Transitions (1999-2000) } \\
\hline & & & (2) \\
\hline & $\begin{array}{l}\text { Children of Non- } \\
\text { Fostering Households }\end{array}$ & & $\begin{array}{l}\text { Children of Non- } \\
\text { Fostering Households }\end{array}$ \\
\hline & & & [Column \%] \\
\hline Enrollment Rate (\% currently enrolled) & 18.3 & Never enrolled (Not enrolled 1999, Not enrolled 2000) & 76.4 \\
\hline Average Age & 9.4 & Discontinued Enrollment (Enrolled1999, Not enrolled 2000) & 2.8 \\
\hline Median Age & 9 & Newly Enrolled (Not enrolled 1999, Enrolled 2000) & 6.1 \\
\hline Percentage Male & 50.9 & Enrolled both years (Enrolled 1999, Enrolled 2000) & 14.7 \\
\hline Number of Children & 470 & Number of Children & 423 \\
\hline
\end{tabular}

\begin{tabular}{lrr|r}
\hline Panel C: Difference in Differences Comparing Average School Enrollment ${ }^{\text {a }}$ & & Difference \\
& $\begin{array}{rrr}\text { Foster Children } \\
(\mathrm{N}=202)\end{array}$ & $\begin{array}{r}\text { Children of Non- } \\
\text { Fostering Households } \\
(\mathrm{N}=423)\end{array}$ & \\
\hline Pre-Fostering & 0.124 & 0.175 & -0.051 \\
& {$[0.023]$} & {$[0.018]$} & {$[0.032]$} \\
Post-Fostering & 0.154 & 0.208 & -0.054 \\
& {$[0.025]$} & {$[0.020]$} & {$[0.034]$} \\
\hline Difference & & 0.033 & -0.003 \\
& 0.030 & {$[0.026]$} & {$[0.046]$} \\
\end{tabular}

Note: Statistics in the table are based on children aged 5 years and older. Panel A contains summary statistics, similar to Table 1, for the children of non-fostering households, and Panel B contains school enrollment transition information, similar to Table 2, for these children. In Panel B, I use 1999 and 2000 enrollment rates for these children, but results are similar using 1998 and 1999 enrollment rates. In Panel B, I exclude 47 children aged 4 in 1999 because they are too young to be enrolled. Data source: Author's survey.

${ }^{a}$ Panel C presents difference in differences results comparing average school enrollment for foster children with children from non-fostering households using pre and post-fostering enrollment for the foster children and 1999 and 2000 enrollment for the other children, with similar results using 1998 and 1999 enrollment for these other children. 
Table 8: Household and Child Fixed Effects Regressions Comparing Host Siblings, Biological Siblings, Foster Children and Children From Non-Fostering Households

\begin{tabular}{|c|c|c|c|c|c|c|c|c|}
\hline \multirow{4}{*}{$\begin{array}{l}\text { Dependent Variable: } \\
\text { School Enrollment }\end{array}$} & \multicolumn{4}{|c|}{ Child Fixed Effects } & \multicolumn{4}{|c|}{ Household Fixed Effects } \\
\hline & (1) & (2) & (3) & (4) & $(5)$ & (6) & $(7)$ & $(8)$ \\
\hline & All & Children & Children & Children & All & Children & Children & Children \\
\hline & Children & Aged 5-7 & Aged 8-11 & Aged $>=12$ & Children & Aged 5-7 & Aged 8-11 & Aged $>=12$ \\
\hline \multirow[t]{2}{*}{ Host*After } & 0.019 & $0.239 * * *$ & 0.023 & $-0.094 * * *$ & -0.004 & -0.045 & 0.005 & -0.036 \\
\hline & {$[0.014]$} & {$[0.043]$} & {$[0.024]$} & {$[0.019]$} & {$[0.021]$} & {$[0.035]$} & {$[0.035]$} & {$[0.034]$} \\
\hline \multirow[t]{2}{*}{ Biological*After } & 0.012 & $0.113 * * *$ & $0.041 * *$ & $-0.054 * * *$ & -0.006 & -0.009 & $0.062 * *$ & $-0.058 * *$ \\
\hline & {$[0.011]$} & {$[0.028]$} & {$[0.018]$} & {$[0.015]$} & {$[0.016]$} & {$[0.026]$} & {$[0.028]$} & {$[0.027]$} \\
\hline \multirow[t]{2}{*}{ Foster*After } & 0.011 & $0.215 * * *$ & $-0.056^{*}$ & -0.015 & 0.041 & $0.182 * * *$ & 0.011 & 0.002 \\
\hline & {$[0.018]$} & {$[0.056]$} & {$[0.031]$} & {$[0.024]$} & {$[0.027]$} & {$[0.050]$} & {$[0.045]$} & {$[0.043]$} \\
\hline \multirow[t]{2}{*}{ Host Sibling } & & & & & $0.196 * * *$ & $0.118 * *$ & $0.181 * * *$ & $0.254 * * *$ \\
\hline & & & & & {$[0.028]$} & {$[0.047]$} & {$[0.049]$} & {$[0.050]$} \\
\hline \multirow[t]{2}{*}{ Biological Sibling } & & & & & $0.081 * * *$ & 0.003 & 0.045 & $0.137 * * *$ \\
\hline & & & & & {$[0.025]$} & {$[0.043]$} & {$[0.044]$} & {$[0.046]$} \\
\hline \multirow[t]{2}{*}{ Male } & & & & & $0.081 * * *$ & $0.047 * * *$ & $0.122 * * *$ & $0.089 * * *$ \\
\hline & & & & & {$[0.010]$} & {$[0.018]$} & {$[0.018]$} & {$[0.018]$} \\
\hline \multirow[t]{2}{*}{ Year $=1999$} & -0.001 & 0.055 & 0.019 & -0.035 & -0.003 & -0.036 & 0.045 & -0.039 \\
\hline & {$[0.015]$} & {$[0.034]$} & {$[0.024]$} & {$[0.023]$} & {$[0.025]$} & {$[0.036]$} & {$[0.043]$} & {$[0.046]$} \\
\hline \multirow[t]{2}{*}{ Year $=2000$} & 0.023 & $0.195 * * *$ & -0.025 & $-0.059 * *$ & 0.016 & 0.058 & 0.004 & -0.072 \\
\hline & {$[0.015]$} & {$[0.038]$} & {$[0.027]$} & {$[0.023]$} & {$[0.025]$} & {$[0.037]$} & {$[0.043]$} & {$[0.044]$} \\
\hline \multirow[t]{2}{*}{ Constant } & $0.231 * * *$ & 0.018 & $0.310 * * *$ & $0.247 * * *$ & $0.076 * * *$ & $0.066 * *$ & $0.172 * * *$ & $0.061 *$ \\
\hline & {$[0.013]$} & {$[0.013]$} & {$[0.009]$} & {$[0.008]$} & {$[0.020]$} & {$[0.030]$} & {$[0.032]$} & {$[0.034]$} \\
\hline Observations & 6656 & 1998 & 2449 & 2209 & 6656 & 1998 & 2449 & 2209 \\
\hline Number of children & 2420 & 1074 & 1222 & 952 & & & & \\
\hline Number of households & & & & & 489 & 445 & 420 & 393 \\
\hline \multicolumn{9}{|c|}{$\begin{array}{l}\text { Note: Standard errors in brackets. *,**, *** indicate significance at } 10 \%, 5 \% \text {, and } 1 \% \text { respectively. Dataset includes } 640 \text { host siblings, } 994 \\
\text { biological siblings, } 316 \text { foster children, and } 470 \text { non-fostering household children measured over } 3 \text { years with the reference group being children } \\
\text { from non-fostering households. Columns } 1 \text { and } 5 \text { exclude } 604 \text { observations in which the children were under age } 5 \text { in a given year. To control for } \\
\text { age effects in columns } 1 \text { and } 5, \text { I also include dummy variables indicating if the child is young or middle aged. In the age restricted columns, I run } \\
\text { the same child or household fixed effects regression but the dataset is restricted to include children of that age range. The year dummies are } \\
\text { interacted with an indicator variable for children from non-fostering households to capture the control group's time trend. Data source: Author's } \\
\text { survey. }\end{array}$} \\
\hline
\end{tabular}


Table 9: OLS Regression Estimating Correlation Between Being Fostered as a Child and Income and Wealth

\begin{tabular}{|c|c|c|c|c|c|c|}
\hline & \multicolumn{3}{|c|}{$\begin{array}{c}\text { Dependent Variable }= \\
\text { Ln (Asset Value) }\end{array}$} & \multicolumn{3}{|c|}{$\begin{array}{c}\text { Dependent Variable }= \\
\text { Ln (Income) }\end{array}$} \\
\hline & (1) & (2) & (3) & (4) & (5) & (6) \\
\hline Fostered as a Child & $\begin{array}{l}0.337 * * \\
{[0.156]}\end{array}$ & $\begin{array}{l}0.279^{*} \\
{[0.154]}\end{array}$ & & $\begin{array}{l}0.433 * * * \\
{[0.141]}\end{array}$ & $\begin{array}{l}0.376^{* * *} \\
{[0.142]}\end{array}$ & \\
\hline Foster duration $<5$ years & & & $\begin{array}{l}0.542 * * \\
{[0.246]}\end{array}$ & & & $\begin{array}{l}0.468 * * \\
{[0.227]}\end{array}$ \\
\hline 5 years $<=$ Foster duration $<=10$ years & & & $\begin{array}{l}0.269 \\
{[0.229]}\end{array}$ & & & $\begin{array}{l}0.402 * \\
{[0.212]}\end{array}$ \\
\hline Foster duration $>10$ years & & & $\begin{array}{l}-0.075 \\
{[0.287]}\end{array}$ & & & $\begin{array}{l}0.204 \\
{[0.264]}\end{array}$ \\
\hline Father in Position of Responsibility & & $\begin{array}{l}-0.183 \\
{[0.146]}\end{array}$ & $\begin{array}{l}-0.213 \\
{[0.147]}\end{array}$ & & $\begin{array}{l}0.049 \\
{[0.134]}\end{array}$ & $\begin{array}{l}0.039 \\
{[0.136]}\end{array}$ \\
\hline Mother in Position of Responsibility & & $\begin{array}{l}0.595 * * \\
{[0.232]}\end{array}$ & $\begin{array}{l}0.569 * * \\
{[0.233]}\end{array}$ & & $\begin{array}{l}0.234 \\
{[0.214]}\end{array}$ & $\begin{array}{l}0.225 \\
{[0.215]}\end{array}$ \\
\hline Number of Father's Wives & & $\begin{array}{l}0.083 * * * \\
{[0.026]}\end{array}$ & $\begin{array}{l}0.083 * * * \\
{[0.026]}\end{array}$ & & $\begin{array}{l}0.028 \\
{[0.024]}\end{array}$ & $\begin{array}{l}0.028 \\
{[0.024]}\end{array}$ \\
\hline Divorced / Widowed & & $\begin{array}{l}-0.407 \\
{[0.365]}\end{array}$ & $\begin{array}{l}-0.408 \\
{[0.364]}\end{array}$ & & $\begin{array}{l}-0.548 \\
{[0.336]}\end{array}$ & $\begin{array}{l}-0.548 \\
{[0.336]}\end{array}$ \\
\hline Never Married & & $\begin{array}{l}-0.063 \\
{[0.378]}\end{array}$ & $\begin{array}{l}-0.067 \\
{[0.378]}\end{array}$ & & $\begin{array}{l}0.192 \\
{[0.348]}\end{array}$ & $\begin{array}{l}0.188 \\
{[0.349]}\end{array}$ \\
\hline $30<$ Age $<=40$ & & $\begin{array}{l}0.350^{*} \\
{[0.182]}\end{array}$ & $\begin{array}{l}0.336^{*} \\
{[0.182]}\end{array}$ & & $\begin{array}{l}0.575 * * * \\
{[0.167]}\end{array}$ & $\begin{array}{l}0.568 * * * \\
{[0.168]}\end{array}$ \\
\hline $40<$ Age $<=50$ & & $\begin{array}{l}0.084 \\
{[0.208]}\end{array}$ & $\begin{array}{l}0.077 \\
{[0.208]}\end{array}$ & & $\begin{array}{l}0.249 \\
{[0.191]}\end{array}$ & $\begin{array}{l}0.245 \\
{[0.192]}\end{array}$ \\
\hline $50<$ Age $<=60$ & & $\begin{array}{l}0.260 \\
{[0.196]}\end{array}$ & $\begin{array}{l}0.276 \\
{[0.197]}\end{array}$ & & $\begin{array}{l}0.272 \\
{[0.181]}\end{array}$ & $\begin{array}{l}0.277 \\
{[0.181]}\end{array}$ \\
\hline Age $>60$ & & $\begin{array}{l}0.141 \\
{[0.206]}\end{array}$ & $\begin{array}{l}0.150 \\
{[0.206]}\end{array}$ & & $\begin{array}{l}0.143 \\
{[0.190]}\end{array}$ & $\begin{array}{l}0.146 \\
{[0.190]}\end{array}$ \\
\hline $\begin{array}{l}\text { Businessman, Teacher, } \\
\text { Government Employee }\end{array}$ & & $\begin{array}{l}0.722 * * * \\
{[0.234]}\end{array}$ & $\begin{array}{l}0.719 * * * \\
{[0.234]}\end{array}$ & & $\begin{array}{l}0.454 * * \\
{[0.215]}\end{array}$ & $\begin{array}{l}0.449 * * \\
{[0.216]}\end{array}$ \\
\hline Unemployed, retired & & $\begin{array}{l}-0.344 \\
{[0.852]}\end{array}$ & $\begin{array}{l}-0.181 \\
{[0.859]}\end{array}$ & & $\begin{array}{l}-1.133 \\
{[0.784]}\end{array}$ & $\begin{array}{l}-1.053 \\
{[0.793]}\end{array}$ \\
\hline Primary Education & & $\begin{array}{l}0.470 * * \\
{[0.208]}\end{array}$ & $\begin{array}{l}0.513 * * \\
{[0.209]}\end{array}$ & & $\begin{array}{l}0.129 \\
{[0.191]}\end{array}$ & $\begin{array}{l}0.149 \\
{[0.193]}\end{array}$ \\
\hline Male & & $\begin{array}{l}1.126^{*} \\
{[0.581]}\end{array}$ & $\begin{array}{l}1.248 * * \\
{[0.588]}\end{array}$ & & $\begin{array}{l}0.443 \\
{[0.535]}\end{array}$ & $\begin{array}{l}0.485 \\
{[0.542]}\end{array}$ \\
\hline Constant & $\begin{array}{l}10.837 * * * \\
{[0.064]}\end{array}$ & $\begin{array}{l}9.182 * * * \\
{[0.612]}\end{array}$ & $\begin{array}{l}9.065^{* * *} \\
{[0.618]}\end{array}$ & $\begin{array}{l}11.160 * * * \\
{[0.058]}\end{array}$ & $\begin{array}{l}10.301 * * * \\
{[0.563]}\end{array}$ & $\begin{array}{l}10.261 * * * \\
{[0.570]}\end{array}$ \\
\hline Observations & 445 & 445 & 445 & 445 & 445 & 445 \\
\hline
\end{tabular}

Note: Standard errors in brackets. *,**,*** indicate significance at $10 \%, 5 \%$, and $1 \%$ respectively. The omitted categories for the dummy variables are age of the respondent is under 30, married for more than 3 years, occupation is farmer, and duration of fostering is never fostered. For those respondents who were fostered, $36 \%$ were fostered for less than 5 years, 39\% were fostered for between 5 and 10 years, and $25 \%$ were fostered for more than 10 years. 
Table 10: OLS and Household Fixed Effects Regressions Using Extended Family Members to Estimate the Impact of Having Been Fostered as a Child on Education, Occupation, and Living in a Rural Village

\begin{tabular}{|c|c|c|c|c|c|c|c|c|}
\hline \multirow[t]{3}{*}{ Dependent Variables: } & \multicolumn{2}{|c|}{ Education } & \multicolumn{2}{|c|}{ "Good" Job } & \multicolumn{2}{|c|}{ Farmer } & \multicolumn{2}{|c|}{ Rural } \\
\hline & (1) & (2) & (3) & (4) & (5) & (6) & (7) & $(8)$ \\
\hline & OLS & HH FE & OLS & HH FE & OLS & HH FE & OLS & HH FE \\
\hline \multirow[t]{2}{*}{ Fostered as a Child } & $0.214 * * *$ & $0.099 * * *$ & $0.223 * * *$ & $0.166^{* * *}$ & $-0.295 * * *$ & $-0.107 * *$ & $-0.215^{* * *}$ & $-0.100 *$ \\
\hline & {$[0.043]$} & {$[0.029]$} & {$[0.046]$} & {$[0.046]$} & {$[0.046]$} & {$[0.054]$} & {$[0.048]$} & {$[0.056]$} \\
\hline \multirow[t]{2}{*}{$30<$ Age $<=40$} & -0.015 & -0.013 & 0.015 & 0.001 & 0.028 & $0.053 *$ & $0.073 * *$ & $0.066 * *$ \\
\hline & {$[0.017]$} & {$[0.016]$} & {$[0.024]$} & {$[0.026]$} & [0.029] & {$[0.030]$} & {$[0.029]$} & {$[0.031]$} \\
\hline \multirow[t]{2}{*}{$40<$ Age $<=50$} & $-0.038 * *$ & $-0.043 * *$ & $-0.045^{*}$ & $-0.056^{*}$ & $0.121 * * *$ & $0.111^{* * *}$ & $0.167 * * *$ & $0.137 * * *$ \\
\hline & {$[0.016]$} & {$[0.021]$} & {$[0.025]$} & {$[0.033]$} & {$[0.031]$} & {$[0.038]$} & {$[0.030]$} & {$[0.040]$} \\
\hline \multirow[t]{2}{*}{$50<$ Age $<=60$} & $-0.053 * * *$ & $-0.068 * * *$ & $-0.058 *$ & $-0.092 * *$ & $0.149 * * *$ & $0.158 * * *$ & $0.188 * * *$ & $0.176 * * *$ \\
\hline & {$[0.018]$} & {$[0.025]$} & {$[0.029]$} & {$[0.041]$} & {$[0.035]$} & {$[0.047]$} & {$[0.035]$} & {$[0.049]$} \\
\hline \multirow[t]{2}{*}{ Age $>60$} & $-0.080 * * *$ & $-0.079 * *$ & $-0.193 * * *$ & $-0.233 * * *$ & $0.195 * * *$ & $0.180 * * *$ & $0.261 * * *$ & $0.271 * * *$ \\
\hline & {$[0.014]$} & {$[0.032]$} & {$[0.027]$} & {$[0.052]$} & {$[0.039]$} & {$[0.060]$} & {$[0.036]$} & {$[0.063]$} \\
\hline \multirow[t]{2}{*}{ Male } & $0.057 * * *$ & $0.059 * * *$ & $0.255 * * *$ & $0.243 * * *$ & $-0.168 * * *$ & $-0.162 * * *$ & $-0.214 * * *$ & $-0.222 * * *$ \\
\hline & {$[0.012]$} & {$[0.012]$} & {$[0.019]$} & {$[0.019]$} & {$[0.022]$} & {$[0.022]$} & {$[0.022]$} & {$[0.023]$} \\
\hline \multirow[t]{2}{*}{ Constant } & $0.055 * * *$ & $0.063 * * *$ & $0.107 * * *$ & $0.129 * * *$ & $0.666 * * *$ & $0.648 * * *$ & $0.673 * * *$ & $0.677 * * *$ \\
\hline & {$[0.011]$} & {$[0.013]$} & {$[0.015]$} & {$[0.021]$} & {$[0.021]$} & {$[0.024]$} & {$[0.020]$} & {$[0.025]$} \\
\hline Observations & 1829 & 1829 & 1829 & 1829 & 1829 & 1829 & 1829 & 1829 \\
\hline Number of Households & & 433 & & 433 & & 433 & & 433 \\
\hline
\end{tabular}

Note: Standard errors in brackets. *,**,*** indicate significance at $10 \%, 5 \%$, and $1 \%$ respectively. All observations in the dataset are brothers and sisters of the head of households. The household fixed effect is for brothers and sisters from the same household. Education is defined as having attended school. "Good" job is defined as the individual being a businessman, government employee, teacher, manual laborer, or other type of employee. Farmer is defined as the individual being a farmer and rural is defined as the person living in a village. The omitted age category is under 30. Data source: Author's survey. 
Appendix Table 1: Household Fixed Effects Estimation Comparing Host Siblings and Biological Siblings

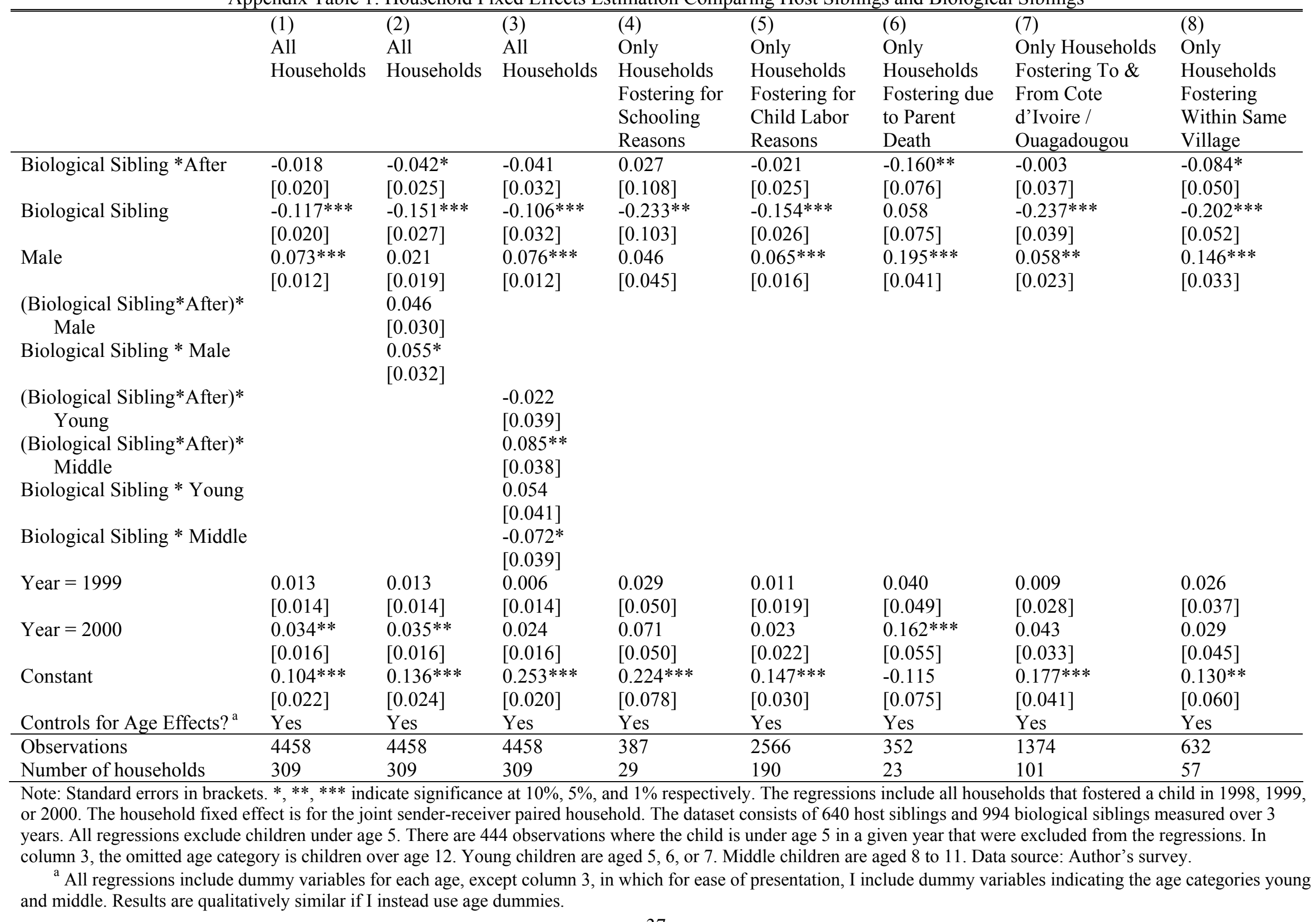

